\title{
DNA methylation in diploid inbred lines of potatoes and its possible role in the regulation of heterosis
}

\author{
Sunao Nakamura · Kazuyoshi Hosaka
}

Received: 4 July 2008/ Accepted: 24 April 2009/Published online: 20 May 2009

(C) The Author(s) 2009. This article is published with open access at Springerlink.com

\begin{abstract}
Self-incompatible diploid potatoes were altered to self-compatible ones by a function of $S$-locus inhibitor gene and continued selfing generated highly homozygous inbreds. In this study, this process was investigated for the status of DNA methylation by a simple method using genomic DNA digested by methylation-sensitive restriction enzymes prior to RAPD analysis. We detected 31 methylation-sensitive RAPD bands, of which 11 were newly appeared in the selfed progenies, and 6 of them stably inherited to subsequent generations. Aberrant segregations and paternal- or atavism-like transmission were also found. Segregating methylation-sensitive bands in initial populations became fixed in the advanced selfed progenies by $75.0-93.8 \%$, of which $41.7 \%$ were fixed to all present and $58.3 \%$ to all absent. Because DNA methylation is generally recognized to suppress gene expression as regulatory factors, homozygosity/heterozygosity of methylated DNA may be involved in inbreeding depression/heterosis.
\end{abstract}

\section{Introduction}

Diploid potatoes and their related wild species (tuberbearing Solanum species) are mostly outbreeding by a gametophytic self-incompatibility system (Pushkarnath

Communicated by J. Bradshaw.

Contribution to the special issue "Heterosis in Plants".

S. Nakamura $\cdot$ K. Hosaka $(\square)$

Food Resources Education and Research Center,

Kobe University, 1348 Uzurano, Kasai,

Hyogo 675-2103, Japan

e-mail: hosaka@kobe-u.ac.jp
1942; Pandey 1962; Cipar et al. 1964). Controlled selfing had been impossible until we found a dominant gene, named $S$-locus inhibitor gene (Sli), which is sporophytically expressed to inhibit a function of $S$-alleles in pollen, and alters self-incompatible plants to self-compatible ones (Hosaka and Hanneman 1998a). The Sli gene was introduced by crossing into cultivated diploid potatoes (Birhman and Hosaka 2000) and continuous selfing produced two series of highly homozygous inbred lines (inbred series A and B) (Phumichai et al. 2005). In the advanced selfed progenies of inbred series A, plants rarely flowered, and self-fertility was very low, but they formed tubers, while those in inbred series B flowered normally, but most of them showed very poor or no pollen shedding and rarely set tubers. Once the two advanced inbred lines were crossed with each other, the inter-inbred hybrids grew vigorously, flowered abundantly, and showed considerably higher tuber set and self-fertility (Phumichai et al. 2005; unpublished data). Thus, these lines experimentally reproduced inbreeding depression and heterosis, and are considered useful materials for a study of the underlying mechanism of heterosis.

Heterosis is a well-known phenomenon showing superiority in hybrid progeny compared with their parents (Shull 1908). Heterosis and inbreeding depression have been considered as two aspects of the same phenomenon (Falconer and Mackay 1996). Dominance, real overdominance, pseudo-overdominance and/or epistasis are the major genetic models proposed to explain heterosis (Lamkey and Edwards 1999; Crow 2000; Reif et al. 2006; Lippman and Zamir 2007). Despite a long dramatic history of successes, especially in maize, there is still a striking discordance between an extensive use of heterosis in variety development and our understanding of the basis of heterosis (Coors and Pandey 1999; Birchler et al. 2003; 
Reif et al. 2006). For instance in rice, Xiao et al. (1995) found, based on marker-assisted quantitative trait locus (QTL) analysis, that dominance is the major genetic basis of heterosis for yield components; however, contradictory results in another study using a similar QTL approach in another rice population reported overdominance and epistasis as the main constituents of heterosis ( $\mathrm{Yu}$ et al. 1997; $\mathrm{Li}$ et al. 2001; Luo et al. 2001). Thus, even for the same traits, in the same organism, different mechanisms were proposed, which points to the complexity of the evidence regarding the genetic basis of heterosis.

The molecular basis of heterosis may be attributed to the increased gene expression level in the hybrid (Leonardi et al. 1991; Romagnoli et al. 1990; Tsaftaris 1995; Tsaftaris et al. 1999) or to the altered regulation of gene expression in the hybrid either at the global level or for specific classes of genes. Two different alleles brought together in the hybrid may create a combined allelic expression pattern in the hybrids. Alternatively, at some loci, allelic interaction or a change in the spectrum of trans-acting factors causes gene expression in the hybrid to deviate from simple additive allelic expression patterns of the parents (Birchler et al. 2003; Gibson and Weir 2005).

DNA methylation, represented by conversion of cytosine to 5-methylcytosine, causes an important change of DNA in vertebrate and plant genomes (Bird 1992; GrantDownton and Dickinson 2005). DNA methyltransferase can transfer a methyl group from $S$-adenosyl-methionine to cytosine in CG dinucleotides. This methylation of cytosine is associated with gene silencing, and genes with abundant 5-methylcytosine in their promoter region are usually transcriptionally silent (Jones and Takai 2001). Thus, DNA methylation does not change the DNA sequence and its function, but does change its expression level, referred as an epigenetic change. Phenotypic variability of synthetic allotetraploids has been shown to involve numerous abnormalities, and the global dominance of one parental phenotype (Heslop-Harrison 1990). A possible contributor to this is epigenetic gene silencing, which is triggered by homologous gene-gene interactions (Meyer and Saedler 1996; Matzke and Matzke 1998). The sudden union of redundant and diverged homologous sets of genes in allopolyploids could trigger widespread gene silencing (Leitch and Bennett 1997; Henikoff and Comai 1998; Rieseberg and Noyes 1998) with accompanying changes in chromatin structure and DNA methylation (Henikoff and Matzke 1997). Synthetic allotetraploids between Arabidopsis thaliana and Cardaminopsis arenosa were indeed phenotypically unstable and less fit than the parents, and demonstrated that $0.4 \%$ of the genes were silenced (Comai et al. 2000). Considering such widespread effects of DNA methylation on gene expression, it might be related to heterosis.
Detection of 5-methylcytosine $\left({ }^{5 \mathrm{~m}} \mathrm{C}\right)$ is primarily based on either using a chemical reaction by sodium bisulfite, which can selectively deaminate cytosine but not 5-methylcytosine to uracil (Clark et al. 1994), or using isoschizomers that differ in their sensitivity to the methylation of their recognition sequences. As most 5-methylcytosine occurs at CG dinucleotides in animals (Doerfler 1983) and at CG and CNG in plants (Gruenbaum et al. 1981), two restriction enzymes, $H p a \mathrm{II}$ and $M s p \mathrm{I}$, are frequently used to detect cytosine methylation. Both enzymes recognize the same sequence $5^{\prime}$-CCGG. However, HpaII is inactive if one or both cytosines are fully methylated (both strands methylated) but cut the hemimethylated sequence (only one DNA strand methylated), whereas $M s p$ I cut $\mathrm{C}^{5 \mathrm{~m}} \mathrm{CGG}$ but not ${ }^{5 \mathrm{~m}}$ CCGG (McClelland et al. 1994). Such differentially digested DNA fragments can be detected by restriction landmark genomic scanning (Hatada et al. 1991), methylation-sensitive arbitrary PCR (Gonzalgo et al. 1997), methylation-sensitive representational difference analysis (Ushijima et al. 1997), or methylation-sensitive amplified polymorphism (MSAP) (Reyna-López et al. 1997). These methods are appropriate for displaying a global picture of DNA methylation changes within a genome, but are laborious and need specific primers and polyacrylamide gel electrophoresis.

In this study, to gain a global view of how methylated DNA inherited through hybridization and successive selfed generations, we detected methylated DNA by simply applying a random amplified polymorphic DNA (RAPD) analysis (Williams et al. 1990) to genomic DNA predigested by methylation-sensitive restriction enzymes of these inbred materials. A discussion on methylated DNA fixed by continuous selfing following a Mendelian fashion lead to the idea that homozygosity/heterozygosity of methylated DNA might be involved in regulating inbreeding depression/heterosis.

\section{Materials and methods}

\section{Plant material}

Pedigrees of the plant materials used in this study are shown in Fig. 1. A diploid clone 97H32-6 (composed of $75 \%$ cultivated and $25 \%$ wild germplasm with $100 \%$ cultivated cytoplasm), designated Parent A throughout this text, was self-compatible due to the function of the Sli gene originally derived from a self-compatible variant of $S$. chacoense (Hosaka and Hanneman 1998a). This clone was selfed consecutively up to $S_{5}$ generation, called inbred series A. The second series of inbred lines (inbred series B) was started from a cross of an advanced diploid clone WB922236-2 (designated Parent B) with the pollen of 


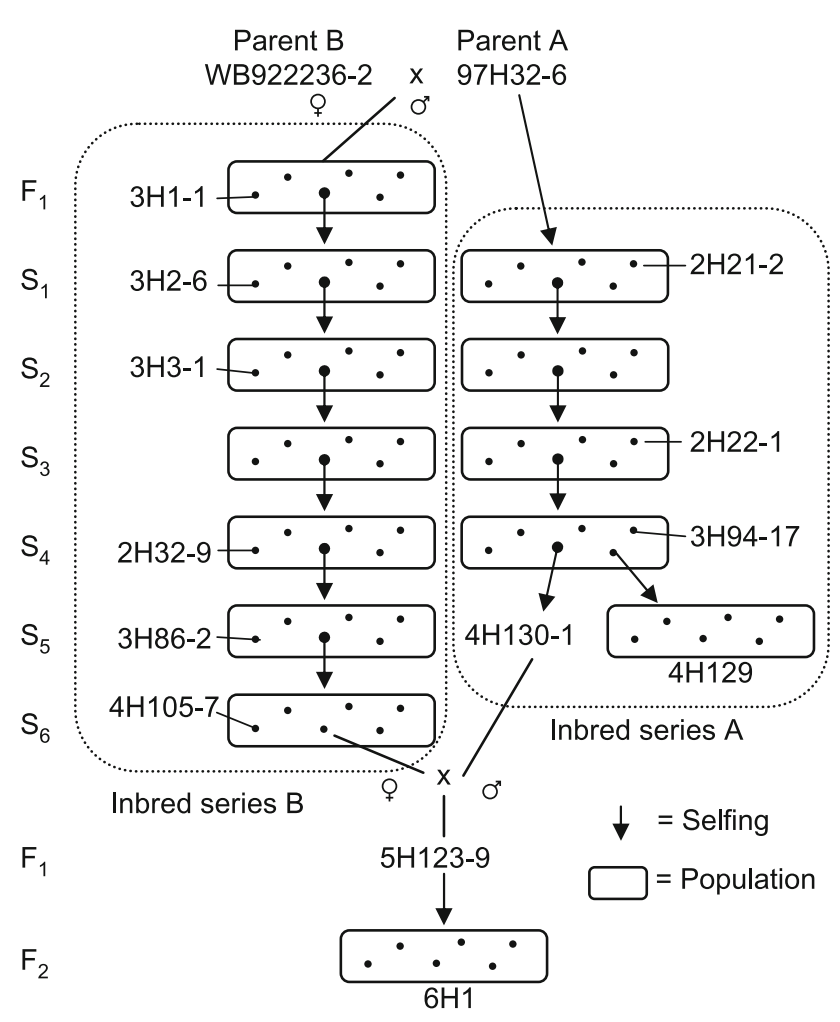

Fig. 1 Pedigrees of the materials used in this study. Two series of diploid potato inbreds A and B were developed from a diploid potato clone having the Sli gene (97H32-6) by successive selfing and from a cross between this clone and another diploid potato WB922236-2, followed by successive selfing, respectively

Parent A. One of the $F_{1}$ plants was consecutively selfed up to the $\mathrm{S}_{6}$ generation. Although thousands of seedlings were raised in every generation, only these two lines reached such selfed generations. Decreasing heterozygosity levels in these inbred series were monitored by heterozygous restriction fragment length polymorphism (RFLP) markers: the initial heterozygosity decreased from $100 \%$ in Parent A to $11.5 \%$ in the $\mathrm{S}_{5}$ population (4H129) (Phumichai and Hosaka 2006), and that of the $\mathrm{F}_{1}(\mathrm{~B} \times \mathrm{A})$ plant $(99 \mathrm{H} 2-1)$ to $12.2 \%$ in the $\mathrm{S}_{5}$ population (3H86) (Phumichai et al. 2005). Although the average rate of reduction in heterozygosity per generation was lower than the theoretically expected rate $(50 \%)$, none of the loci was exclusively heterozygous in the advanced self-progeny, and consequently, highly homozygous inbreds were obtained (Phumichai et al. 2005). One such highly homozygous $S_{6}$ plant (4H105-5) was pollinated with pollen of an $\mathrm{S}_{5}$ plant of inbred series $A$ (4H130-1), resulting in an $\mathrm{F}_{1}$ plant (5H123-9) from which an $\mathrm{F}_{2}$ family $(6 \mathrm{H} 1)$ was generated by selfing.

In the first experiment, methylation status was investigated for the parents and one individual randomly chosen from each selfed generation except for $4 \mathrm{H} 130-1$, the $\mathrm{S}_{5}$ parent of the $F_{1}$ plant 5H123-9 (Fig. 1). There were no available DNA stocks for $S_{2}$ of inbred series $A$ and $S_{3}$ of inbred series B. For comparison between initial and advanced populations in the second experiment, $13 \mathrm{~S}_{1}(2 \mathrm{H} 21)$ and $11 \mathrm{~S}_{5}$ (4H129) plants in the inbred series A, $20 \mathrm{~F}_{1}$ (3H1) and $15 \mathrm{~S}_{6}$ (4H105) plants in the inbred series B, and $18 \mathrm{~F}_{2}(6 \mathrm{H} 1)$ plants were used.

\section{Detection of methylation-sensitive RAPD bands}

Total DNA was extracted from fresh leaves by the method of Hosaka and Hanneman (1998b) and stored at $-30^{\circ} \mathrm{C}$ until use. Approximately $8 \mu \mathrm{g}$ of DNA was digested completely by overnight incubation at $37^{\circ} \mathrm{C}$ with 25 units of MspI (Takara Bio Inc., Japan) or 12 units of HpaII (Toyobo Co., Ltd., Japan). Restriction enzymes HpaII and $M s p$ I recognize the same four-base sequence (CCGG) and cut DNA depending on the methylation status of internal cytosine. HpaII does not cut DNA if the internal cytosine (CCGG) is methylated, whereas $M s p I$ is insensitive to the methylation status of the internal cytosine. Restrictiondigested DNA was precipitated by ethanol, dried, and resuspended in $50 \mu \mathrm{l}$ of distilled water. DNA concentration was measured by DyNA Quant ${ }^{\mathrm{TM}} 200$ (Hoefer Pharmacia Biotech Inc., CA, USA) and adjusted to $5 \mathrm{ng} / \mu \mathrm{l}$. RAPD amplification was performed with $2 \mu \mathrm{l}$ of the above DNA in volumes of $10 \mu \mathrm{l}$ consisting of $0.2 \mu \mathrm{M}$ decamer primer, $5 \mu \mathrm{l}$ of Ampdirect ${ }^{\circledR}$ Plus (Shimadzu Co., Japan) and 0.25 unit Taq DNA polymerase (Nova $T_{a q}{ }^{\mathrm{TM}}$ Hot Start DNA polymerase, Novagen ${ }^{\circledR}$, USA). Thermal cycling was performed using the Gene Amp ${ }^{\circledR}$ PCR System 9700 (Applied Biosystems) (one cycle of $10 \mathrm{~min}$ at $95^{\circ} \mathrm{C}$, followed by 45 cycles of $1 \mathrm{~min}$ at $94^{\circ} \mathrm{C}, 1 \mathrm{~s}$ at $42^{\circ} \mathrm{C}, 30 \%$ transition efficiency towards $36^{\circ} \mathrm{C}, 1 \mathrm{~min}$ at $36^{\circ} \mathrm{C}, 2 \mathrm{~min}$ at $72^{\circ} \mathrm{C}$, and then, terminated with 1 cycle of $5 \mathrm{~min}$ at $72^{\circ} \mathrm{C}$ ). PCR products were separated by electrophoresis on a $1.4 \%$ agarose gel.

\section{Data analysis}

If a methylation-sensitive RAPD band within a population was segregating for presence versus absence, the segregation was tested by $\chi^{2}$ test against an expected ratio. As RAPD bands are generally dominant markers, $3: 1$ is an expected ratio for a selfed progeny and a hybrid progeny from a cross between parents both showing the band. If only one of parents shows the band, 1:1 is an expected ratio in the hybrid progeny. The average heterozygosity of a population $(H)$ was estimated as

$H=\left(\sum 2 p_{i} q_{i}\right) / n$

where $q_{i}$ indicates the square root of the frequency of the $i$ th band absent in the population, $\mathrm{n}$ indicates the total marker bands scored, and $p_{i}=1-q_{i}$. 


\section{Results}

Detection of methylation-sensitive RAPD bands

Using parents and one plant per generation, 31 methylation-sensitive RAPD bands from 21 primers were found from a total of 106 primers screened, which appeared present in the DNA samples pre-digested by HpaII, but absent in those by MspI. Reproducibility was confirmed by repeated PCR using the same DNA samples, whereas repeated DNA extraction was impossible because these plants were only a fraction of many plants for the generations and those not saved as tuber clones. Some bands were specifically observed in the DNA samples predigested by MspI, but those were mostly single plant-specific and irreproducible with repeated experiments. Thus, only HpaII digested DNA-specific bands were regarded as methylation-sensitive bands and designated by primer identity numbers, and if multiple bands with the same primer were detected, alphabets were suffixed.

As shown in Fig. 2a, bands $143 \mathrm{a}$ and $143 \mathrm{c}$ were absent in MspI pre-digested samples, while they were present in HpaII pre-digested samples and undigested ones as well. These bands were regarded as methylation-sensitive bands, because the internal cytosine of the recognition site, flanked by the primer No. 143, was likely full-methylated and thus, HpaII was unable to cut, being equivalent to undigested DNA in the relevant region. These sets of PCR products from undigested, HpaII pre-digested and MspI pre-digested DNA were ethanol-precipitated and cut again by MspI (Fig. 2b) or HpaII (Fig. 2c) for the second digestion. As expected, such methylation-sensitive bands were all cut and disappeared, because PCR products were no longer methylated.

Methylation-sensitive bands detected in hybrid and selfed progenies

In Parent A and its selfed progenies, 18 methylation-sensitive bands were found (Table 1). Eleven of them (61.1\%) were detected in all generations, while band 143a was detected from Parent A to $\mathrm{S}_{4}$ (Fig. 3), and bands 41a and 131 to $S_{1}$. Two bands detected in Parent $A$ (bands 78 and 181) were no longer detected in $S_{1}$. Interestingly, bands $72 \mathrm{c}$ and $143 \mathrm{c}$ were detected in all generations except $\mathrm{S}_{1}$.

Of the 18 methylation-sensitive bands detected in the male parent (Parent A) and 15 in the female parent (Parent B), 11 were common and all but band 115 were detected in one of the $\mathrm{F}_{1}$ (Parent $\mathrm{B} \times$ Parent $\mathrm{A}$ ) plants. Four of seven Parent A-specific bands $(57.1 \%)$ and three of four Parent B-specific bands $(75.0 \%)$ were detected in this $\mathrm{F}_{1}$ plant. As a result, 17 bands were detected in this $F_{1}$ plant, of which eight were detected in all subsequent selfed progenies, and (a)

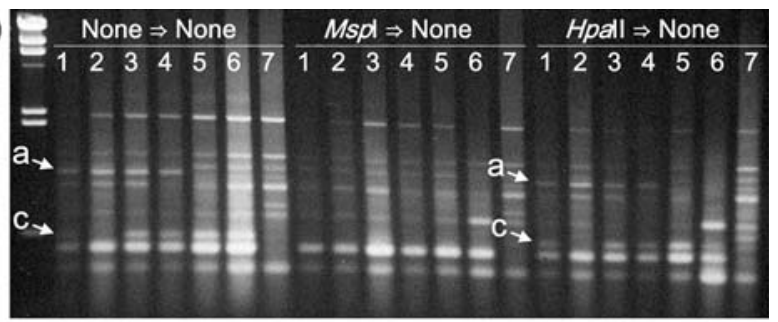

(b)

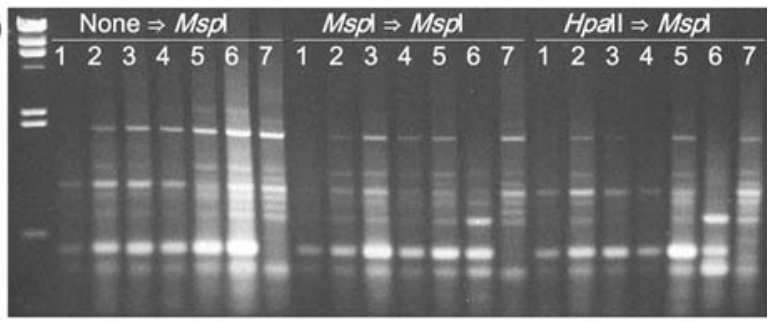

(c)

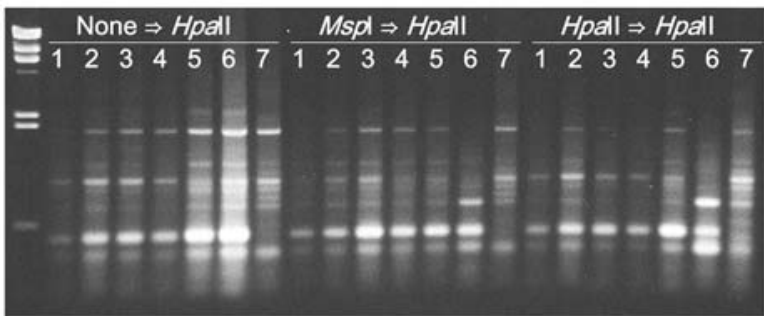

Fig. 2 Effects of the DNA methylation-sensitive restriction enzyme on the RAPD bands 143a and 143c (arrowed). First, non-, MspI- and HpaII-digested DNA samples were amplified by PCR using the decamer primer No. 143. Then, PCR products were digested with (a) no restriction enzyme, (b) MspI or (c) HpaII. Lambda DNA HindIII digests in the furthest left lane. Parent A, 2H21-2 $\left(\mathrm{S}_{1}\right), 2 \mathrm{H} 22-1\left(\mathrm{~S}_{3}\right)$, 3H94-17 $\left(\mathrm{S}_{4}\right), 4 \mathrm{H} 130-1\left(\mathrm{~S}_{5}\right), 5 \mathrm{H} 123-9\left(\mathrm{~F}_{1}\right), 4 \mathrm{H} 105-7\left(\mathrm{~S}_{6}\right)$ (lanes 1-7)

six and three disappeared after one, or more than one selfing, respectively. Newly appeared bands were also detected; five bands just in a certain generation plant, but band 53 first in $S_{1}$, bands $72 \mathrm{a}$ and 172 first in $S_{2}$ and bands $41 \mathrm{a}, 41 \mathrm{~b}$ and $72 \mathrm{c}$ first in $\mathrm{S}_{4}$ and all subsequent generations (Table 1).

In one of the $F_{1}$ plants from a cross between the $S_{6}$ plant of the inbred series $B$ as female and $S_{5}$ of the inbred series $\mathrm{A}$ as male, nine bands common between the parents were all detected. Five of six female parent-specific bands $(83.3 \%)$ and three of four male parent-specific bands $(75.0 \%)$ were detected in the $\mathrm{F}_{1}$ plant.

\section{Changes of methylation-sensitive RAPD bands} between populations

Of the 18 methylation-sensitive bands detected in Parent A, six bands were detected in all 13 plants of the $S_{1}$ population (Table 2). Twelve bands were segregating for presence/ absence within the population, of which two bands were significantly less frequent according to the $\chi^{2}$ test against an expected 3:1 ratio segregation. After 4 consecutive selfings to $S_{5}$, the 6 bands previously shown in all $S_{1}$ plants 
Table 1 Methylation-sensitive bands detected among parental diploid potato clones, their hybrids and selfed progenies

\begin{tabular}{|c|c|c|c|c|c|c|c|c|c|c|c|c|c|}
\hline \multirow[t]{2}{*}{ Band } & \multicolumn{7}{|c|}{ Inbred series B } & \multirow{2}{*}{$\begin{array}{l}\text { Inter-inbred } \\
\mathrm{F}_{1}\left(\mathrm{~S}_{6} \times \mathrm{S}_{5}\right)\end{array}$} & \multicolumn{5}{|c|}{ Inbred series A } \\
\hline & Parent B & $\mathrm{F}_{1}(\mathrm{~B} \times \mathrm{A})$ & $\mathrm{S}_{1}$ & $\mathrm{~S}_{2}$ & $\mathrm{~S}_{4}$ & $\mathrm{~S}_{5}$ & $\mathrm{~S}_{6}$ & & $\mathrm{~S}_{5}$ & $\mathrm{~S}_{4}$ & $\mathrm{~S}_{3}$ & $\mathrm{~S}_{1}$ & Parent A \\
\hline $41 \mathrm{a}$ & - & - & - & - & + & + & + & + & - & - & - & + & + \\
\hline $41 b$ & - & - & - & - & + & + & + & + & - & - & - & - & - \\
\hline $46 a$ & - & + & + & + & + & + & + & + & + & + & + & + & + \\
\hline $46 \mathrm{~b}$ & + & + & - & - & - & - & - & - & - & - & - & - & - \\
\hline $46 c$ & - & - & - & - & - & - & - & - & + & + & + & + & + \\
\hline 53 & - & - & + & + & + & + & + & + & - & - & - & - & - \\
\hline 60 & - & + & - & - & - & - & - & + & + & + & + & + & + \\
\hline 69 & + & + & - & - & - & - & - & - & - & - & - & - & - \\
\hline $72 \mathrm{a}$ & - & - & - & + & + & + & + & + & - & - & - & - & - \\
\hline $72 b$ & + & + & - & - & - & - & - & + & + & + & + & + & + \\
\hline $72 c$ & - & - & - & - & + & + & + & + & + & + & + & - & + \\
\hline 78 & + & + & + & + & - & - & - & - & - & - & - & - & + \\
\hline $88 \mathrm{a}$ & + & + & + & + & + & + & + & + & + & + & + & + & + \\
\hline $88 \mathrm{~b}$ & + & + & + & + & + & + & + & + & + & + & + & + & + \\
\hline 115 & + & - & + & + & + & + & + & + & + & + & + & + & + \\
\hline $121 \mathrm{a}$ & + & + & + & + & + & + & + & + & + & + & + & + & + \\
\hline $121 b$ & - & - & - & - & + & - & - & - & - & - & - & - & - \\
\hline $121 \mathrm{c}$ & - & - & - & - & - & - & - & - & - & - & - & - & - \\
\hline 131 & - & + & + & + & - & - & - & - & - & - & - & + & + \\
\hline $143 a$ & + & + & + & + & - & - & - & - & - & + & + & + & + \\
\hline $143 b$ & - & - & - & - & - & - & - & - & - & - & - & - & - \\
\hline $143 \mathrm{c}$ & + & + & - & - & - & - & - & + & + & + & + & - & + \\
\hline 145 & + & + & + & + & + & + & + & + & + & + & + & + & + \\
\hline 149 & + & + & + & + & + & + & + & + & - & - & - & - & - \\
\hline 153 & + & - & - & - & - & - & - & - & - & - & - & - & - \\
\hline 161 & + & + & + & + & + & + & + & + & + & + & + & + & + \\
\hline 172 & - & - & - & + & + & + & + & - & - & - & - & - & - \\
\hline 177 & - & - & + & - & - & - & - & - & - & - & - & - & - \\
\hline 181 & - & + & - & - & - & - & - & - & - & - & - & - & + \\
\hline 218 & + & + & + & + & + & + & + & + & + & + & + & + & + \\
\hline 220 & - & - & - & + & - & - & - & - & - & - & - & - & - \\
\hline Total $^{\mathrm{a}}$ & 15 & 17 & 14 & 17 & 16 & 16 & 15 & 17 & 13 & 14 & 14 & 14 & 18 \\
\hline
\end{tabular}

Presence (+) or absence (-) of HpaII digests-specific RAPD bands that were not detected in those from the isoschizomer MspI is shown Parent B, WB922236-2; $\mathrm{F}_{1}(\mathrm{~B} \times \mathrm{A}), 3 \mathrm{H} 1-1 ; \mathrm{S}_{1}, 3 \mathrm{H} 2-6 ; \mathrm{S}_{2}, 3 \mathrm{H} 3-1 ; \mathrm{S}_{4}, 2 \mathrm{H} 32-9 ; \mathrm{S}_{5}, 3 \mathrm{H} 86-2 ; \mathrm{S}_{6}, 4 \mathrm{H} 105-7 ; \mathrm{F}_{1}\left(\mathrm{~S}_{6} \times \mathrm{S}_{5}\right), 5 \mathrm{H} 123-9 ; \mathrm{S}_{5}, 4 \mathrm{H} 130-1$; $\mathrm{S}_{4}, 3 \mathrm{H} 94-17 ; \mathrm{S}_{3}, 2 \mathrm{H} 22-1 ; \mathrm{S}_{1}, 2 \mathrm{H} 21-2$; Parent A, 97H32-6. See Fig. 1 for the pedigree relationships among these materials

a Total number of present bands

were also shown in all $\mathrm{S}_{5}$ plants, while $9(75.0 \%)$ of the 12 segregating bands in $S_{1}$ were fixed to all present (5 bands) or all absent (4 bands) among 11 plants. Based on the proportion of segregating bands in $\mathrm{S}_{1}$, the heterozygosity in Parent A was 0.667 (12/18). The average heterozygosity $(H)$ in $\mathrm{S}_{1}$ was 0.309 , which dramatically decreased to 0.074 in $S_{5}$ (Table 2).

Parent A as male and B as female, and their $20 \mathrm{~F}_{1}$ and 15 $\mathrm{S}_{6}$ plants in the inbred series B were examined for methylation-sensitive bands. Eleven bands were detected in either one of parents, and another 11 in both parents. Of the 11 common bands, 5 were detected in all $\mathrm{F}_{1}$ plants, while the remaining 6 were segregating. Only band 218 was significantly over-represented from an expected 3:1 segregation ratio. In the $F_{1}$ population, seven bands were derived specifically from the male parent; band 46a was all present, five segregated normally, and one was over-represented with significant deviation from an 1:1 ratio. On the other hand, four bands were derived specifically from the female parent and segregated normally except band 


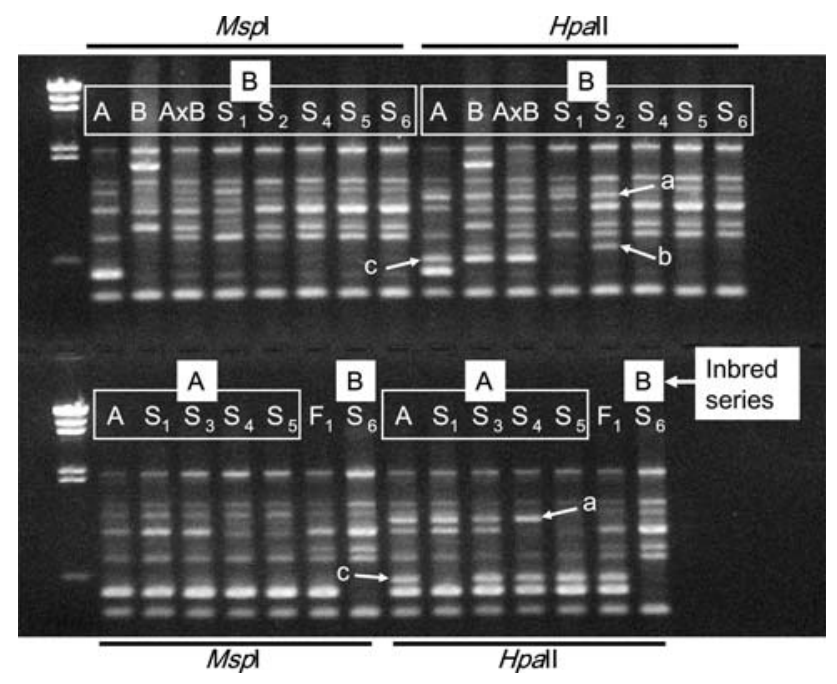

Fig. 3 Dynamic changes of the DNA methylation-sensitive bands 143a, 143b and 143c (arrowed) by selfing and hybridization, detected in the RAPD patterns of amplified products from MspI- and HpaIIdigested DNA using the decamer primer No. 143. Lambda DNA HindIII digests in the most left lane

Table 2 Frequency change of the methylation-sensitive bands of the diploid potato clone $97 \mathrm{H} 32-6$ (Parent $\mathrm{A})$ in $\mathrm{S}_{1}(2 \mathrm{H} 21$ population) and $\mathrm{S}_{5}$ (4H129 population)

\begin{tabular}{|c|c|c|c|c|c|c|}
\hline \multirow[t]{2}{*}{ Band } & \multicolumn{3}{|c|}{$\mathrm{S}_{1}$ population } & \multicolumn{3}{|c|}{$\mathrm{S}_{5}$ population } \\
\hline & + & - & $\chi^{2}$ value $^{\mathrm{a}}$ & + & - & $\chi^{2}$ value $^{\mathrm{a}}$ \\
\hline $41 \mathrm{a}$ & 10 & 3 & 0.03 & 0 & 11 & - \\
\hline $46 a$ & 13 & 0 & - & 11 & 0 & - \\
\hline $46 c$ & 9 & 4 & 0.23 & 11 & 0 & - \\
\hline 60 & 13 & 0 & - & 11 & 0 & - \\
\hline $72 b$ & 13 & 0 & - & 11 & 0 & - \\
\hline $72 \mathrm{c}$ & 9 & 4 & 0.23 & 11 & 0 & - \\
\hline 78 & 8 & 5 & 1.26 & 0 & 11 & - \\
\hline $88 \mathrm{a}$ & 13 & 0 & - & 11 & 0 & - \\
\hline $88 \mathrm{~b}$ & 13 & 0 & - & 11 & 0 & - \\
\hline 115 & 12 & 1 & 2.08 & 11 & 0 & - \\
\hline $121 \mathrm{a}$ & 13 & 0 & - & 11 & 0 & - \\
\hline 131 & 8 & 5 & 1.26 & 0 & 11 & - \\
\hline $143 \mathrm{a}$ & 11 & 2 & 0.64 & 6 & 5 & 2.46 \\
\hline $143 \mathrm{c}$ & 6 & 7 & $5.77 *$ & 11 & 0 & - \\
\hline 145 & 6 & 7 & $5.77 *$ & 11 & 0 & - \\
\hline 161 & 10 & 3 & 0.03 & 10 & 1 & 1.49 \\
\hline 181 & 9 & 4 & 0.23 & 0 & 11 & - \\
\hline 218 & 11 & 2 & 0.64 & 7 & 4 & 0.76 \\
\hline$H=$ & & & & & & \\
\hline
\end{tabular}

The number of plants showing the marker band $(+)$, or those not showing it ( - ), and the average heterozygosity $(H)$ for each population are shown

* Significant deviation at $5 \%$ level

a Presence versus absence of the band was tested by $\chi^{2}$ test against a 3:1 ratio
149, which was significantly over-represented. Of six bands detected in all $\mathrm{F}_{1}$ plants, five were also detected in all $\mathrm{S}_{6}$ plants, whereas band $72 \mathrm{~b}$ was interestingly never found in $S_{6}$. Fifteen $(93.8 \%)$ of the 16 segregating bands in $F_{1}$ were fixed to all present ( 5 bands) or all absent (10 bands) in $S_{6}$. Four bands (41b, 53, 72a and 172) were all present in $\mathrm{S}_{6}$, which had never been detected in the parents or $\mathrm{F}_{1}$ plants. The average heterozygosity $(H)$ decreased from 0.259 in $F_{1}$ to 0.018 in $S_{6}$.

Nineteen methylation-sensitive bands were detected in one of inter-inbred $F_{1}$ hybrids $\left(S_{6} \times S_{5}\right)$ and its parents. However, because an additional band was detected using primer No. 53 in the $F_{2}$ population (18 plants), 20 bands were actually examined (Table 4). Nine bands were common in both parents and its $F_{1}$ plant, among which 8 bands were detected in all $18 \mathrm{~F}_{2}$ plants. The remaining one band (band 218) was significantly under-represented in the $F_{2}$ population. Eight bands were detected in one of parents and the $F_{1}$ plant, among which seven bands were segregating with an expected 3:1 ratio segregation in the $F_{2}$. The remaining band $72 \mathrm{~b}$ seemed paternally transmitted from the male parent through the $F_{1}$ to all the $F_{2}$ plants. Bands $46 \mathrm{c}$ of the male parent and 172 of the female parent were not observed in the $F_{1}$ plant, but strangely appeared again in 2 and $6 \mathrm{~F}_{2}$ plants, respectively, and showed skewed segregations. Primer No. 53 produced an additional new band, which appeared in all $\mathrm{F}_{2}$ plants. Based on the proportion of segregating bands in the $F_{2}$ population, the heterozygosity in the $F_{1}$ plant was $0.500(10 / 20)$. Alternatively, since three of 20 bands were absent in the $F_{1}$ plant, the heterozygosity could be estimated as $H=$ $2 p q=2 \times(3 / 20)^{-2} \times\left[1-(3 / 20)^{-2}\right]=0.475$. By one selfing, the average heterozygosity was decreased to 0.204 (Tables 3, 4).

\section{Discussion}

A simple detection method of methylated DNA was developed in this study simply by an addition of methylation-sensitive restriction digestion of genomic DNA prior to RAPD analysis, the simplest method for detection of DNA polymorphisms (Rafalski and Tingey 1993; Powell et al. 1996). The scored RAPD bands were clarified as methylation-sensitive DNA fragments by second restriction digestion, which could this time cut the fragments (Fig. 2), because PCR generated non-methylated DNA. This simple method is useful for a rapid and global survey of a genome for DNA methylation.

It has been widely recognized that, in contrast to the general rule of "erase-and-reset" cytosine methylation dynamics in each generation in animals, parental methylation states in plants are often stably inherited to sexual 
Table 3 Methylation-sensitive bands detected in the diploid potato clone of either Parent A (97H32-6) or B (WB922236-2), and the frequency change in their $\mathrm{F}_{1}\left(=\mathrm{S}_{0}\right)$ (3H1 population) and its $\mathrm{S}_{6}$ (4H105 population)

\begin{tabular}{|c|c|c|c|c|c|c|c|c|}
\hline \multirow[t]{2}{*}{ Band } & \multirow[t]{2}{*}{ B (甲) } & \multirow[t]{2}{*}{$\mathrm{A}(\hat{\jmath})$} & \multicolumn{3}{|c|}{$\mathrm{F}_{1}$ population } & \multicolumn{3}{|c|}{$\mathrm{S}_{6}$ population } \\
\hline & & & + & - & $\overline{\chi^{2} \text { value }^{a}}$ & + & - & $\chi^{2}$ value $^{b}$ \\
\hline $41 \mathrm{a}$ & - & + & 8 & 12 & 0.80 & 15 & 0 & - \\
\hline $41 b$ & - & - & 0 & 20 & - & 15 & 0 & - \\
\hline $46 a$ & - & + & 20 & 0 & - & 15 & 0 & - \\
\hline $46 b$ & + & - & 11 & 9 & 0.20 & 0 & 15 & - \\
\hline $46 c$ & - & + & 9 & 11 & 0.20 & 0 & 15 & - \\
\hline 53 & - & - & 0 & 20 & - & 15 & 0 & - \\
\hline 60 & - & + & 16 & 4 & $7.20 * *$ & 0 & 15 & - \\
\hline 69 & + & - & 9 & 11 & 0.20 & 0 & 15 & - \\
\hline $72 \mathrm{a}$ & - & - & 0 & 20 & - & 15 & 0 & - \\
\hline $72 b$ & + & + & 20 & 0 & - & 0 & 15 & - \\
\hline $72 \mathrm{c}$ & - & + & 8 & 12 & 0.80 & 15 & 0 & - \\
\hline 78 & + & + & 12 & 8 & 2.40 & 0 & 15 & - \\
\hline $88 \mathrm{a}$ & + & + & 20 & 0 & - & 15 & 0 & - \\
\hline $88 \mathrm{~b}$ & + & + & 20 & 0 & - & 15 & 0 & - \\
\hline 115 & + & + & 12 & 8 & 2.40 & 15 & 0 & - \\
\hline $121 \mathrm{a}$ & + & + & 20 & 0 & - & 15 & 0 & - \\
\hline 131 & - & + & 11 & 9 & 0.20 & 0 & 15 & - \\
\hline $143 a$ & + & + & 18 & 2 & 2.40 & 0 & 15 & - \\
\hline $143 c$ & + & + & 16 & 4 & 0.27 & 0 & 15 & - \\
\hline 145 & + & + & 20 & 0 & - & 15 & 0 & - \\
\hline 149 & + & - & 16 & 4 & $7.20 * *$ & 15 & 0 & - \\
\hline 153 & + & - & 6 & 14 & 3.20 & 0 & 15 & - \\
\hline 161 & + & + & 12 & 8 & 2.40 & 15 & 0 & - \\
\hline 172 & - & - & 0 & 20 & - & 15 & 0 & - \\
\hline 181 & - & + & 12 & 8 & 0.80 & 0 & 15 & - \\
\hline 218 & + & + & 19 & 1 & $4.27 *$ & 9 & 6 & 1.80 \\
\hline$H=$ & & & 0.259 & & & 0.018 & & \\
\hline
\end{tabular}

The number of plants showing the marker band $(+)$, or those not showing it $(-)$, and the average heterozygosity $(H)$ for each population are shown

Newly detected bands in the $\mathrm{S}_{6}$ plant (4H105-7) were also included **** Significant deviation at $5 \%$ and $1 \%$ levels, respectively

${ }^{\text {a }}$ Presence versus absence of the band was tested by $\chi^{2}$ test against a $3: 1$ or $1: 1$ ratio if both parents or only one parent showed the band, respectively

b Against a 3:1 ratio

progenies (Cubas et al. 1999; Kakutani 2002; Riddle and Richards 2002). Nevertheless, it was observed in various plant taxa that the formation of inter-specific hybrids and allopolyploids is often accompanied by remodeling of the otherwise additive parental methylation patterns (Madlung et al. 2002; Liu and Wendel 2003; Levy and Feldman 2004; Salmon et al. 2005; Lukens et al. 2006; Marfil et al. 2006). Parental methylation states of at least some genomic loci may also be modified by trans-acting modifiers in certain
Table 4 Methylation-sensitive bands detected in the diploid potato clone of either an $\mathrm{S}_{5}$ plant of the inbred series A (4H130-1), an $\mathrm{S}_{6}$ plant of the inbred series B (4H105-7) or the $\mathrm{F}_{1}$ hybrid (5H123-9), and their frequencies in the $\mathrm{F}_{2}(6 \mathrm{H} 1$ population)

\begin{tabular}{|c|c|c|c|c|c|c|}
\hline \multirow[t]{2}{*}{ Band } & \multirow[t]{2}{*}{$\mathrm{S}_{6}(+)$} & \multirow[t]{2}{*}{$\mathrm{S}_{5}(\hat{\jmath})$} & \multirow[t]{2}{*}{$\mathrm{F}_{1}\left(\mathrm{~S}_{6} \times \mathrm{S}_{5}\right)$} & \multicolumn{3}{|c|}{$\mathrm{F}_{2}$ population } \\
\hline & & & & + & - & $\overline{\chi^{2} \text { value }^{a}}$ \\
\hline $41 \mathrm{a}$ & + & - & + & 13 & 5 & 0.07 \\
\hline $41 \mathrm{~b}$ & + & - & + & 16 & 2 & 1.85 \\
\hline $46 a$ & + & + & + & 18 & 0 & - \\
\hline $46 c$ & - & + & - & 2 & 16 & $39.19 * *$ \\
\hline 53 & + & - & + & 13 & 5 & 0.07 \\
\hline $53^{\mathrm{a}}$ & - & - & - & 18 & 0 & - \\
\hline 60 & - & + & + & 11 & 7 & 1.85 \\
\hline $72 \mathrm{a}$ & + & - & + & 15 & 3 & 0.67 \\
\hline $72 b$ & - & + & + & 18 & 0 & - \\
\hline $72 \mathrm{c}$ & + & + & + & 18 & 0 & - \\
\hline $88 \mathrm{a}$ & + & + & + & 18 & 0 & - \\
\hline $88 \mathrm{~b}$ & + & + & + & 18 & 0 & - \\
\hline 115 & + & + & + & 18 & 0 & - \\
\hline $121 \mathrm{a}$ & + & + & + & 18 & 0 & - \\
\hline $143 \mathrm{c}$ & - & + & + & 13 & 5 & 0.07 \\
\hline 145 & + & + & + & 18 & 0 & - \\
\hline 149 & + & - & + & 12 & 6 & 0.67 \\
\hline 161 & + & + & + & 18 & 0 & - \\
\hline 172 & + & - & - & 6 & 12 & $16.67 * *$ \\
\hline 218 & + & + & + & 6 & 12 & $16.67 * *$ \\
\hline$H=$ & & & 0.475 & 0.204 & & \\
\hline
\end{tabular}

The number of plants showing the marker band $(+)$, or those not showing it $(-)$, and the average heterozygosity $(H)$ are shown

Presence versus absence of the band was tested by $\chi^{2}$ test against a 3:1 ratio

** Significant deviation at $1 \%$ level

a Newly detected band in the $\mathrm{F}_{2}$ population

intra-specific hybrids between different ecotypes in Arabidopsis (Riddle and Richards 2005) and in several intraspecific maize hybrids (Zhao et al. 2007). Recently, Zhang et al. (2007) showed that, in sorghum, although a great majority of the cytosine methylation sites within the CCGG motifs manifested stable inheritance from inbred parents to hybrids, from 1.69 to $3.22 \%$ of the sites showed deviation from expected parental additivity. We observed, in this study, 11 methylation-sensitive bands newly appeared in the selfed progenies, of which 6 were stably inherited to subsequent generations. In addition, one new band appeared in the $F_{2}$ population of an inter-inbred $F_{1}$ hybrid $\left(S_{6} \times S_{5}\right)$. Aberrant segregation ratios in the populations ( 8 bands) and paternal inheritance-like (1 band) or atavism-like ( 2 bands) transmission were found. All these showed non-Mendelian, or epigenetic fashions in inheritance. Therefore, taken together, this suggests that DNA methylation partly functions epigenetically and dynamically over generations to 
control and compromise with unbalanced gene expressions caused under certain circumstances, such as when genetically differentiated genomes are brought together into a common nucleus by hybridization, or when consecutive selfing of heterozygous plants brings about homozygosity in certain loci (further discussed below) (Madlung et al. 2002; Chan et al. 2005; Grant-Downton and Dickinson 2006; Zhang et al. 2007).

Methylation-sensitive bands segregating in an initial population, though genetically homozygous for the CCGG motif, became fixed in an advanced selfed population to the extent $75.0 \%$ in the inbred series $A$ and $93.8 \%$ in the inbred series B, of which $41.7 \%$ were fixed to all present and $58.3 \%$ to all absent. The heterozygosity of methylated DNA reduced from 0.667 in Parent A, 0.309 in $S_{1}$, to 0.074 in $\mathrm{S}_{5}$ in the inbred series $\mathrm{A}$, while in the inbred series $\mathrm{B}$ it reduced from 0.259 in $F_{1}(B \times A)$ to 0.018 in $S_{6}$. By crossing between $S_{6}$ and $S_{5}$, it increased to 0.475 in the $F_{1}$, and reduced again to 0.204 in the $\mathrm{F}_{2}$. As RAPD markers are dominant markers, all present in a population does not necessarily mean that the marker is genetically fixed; both heterozygote (Aa) and homozygote (AA) produce the marker band. However, these inbreds had been monitored by codominant RFLP markers for heterozygosity in each selfed generation: $87.8-88.5 \%$ of parental heterozygous loci became homozygous in $\mathrm{S}_{5}$ (Phumichai et al. 2005; Phumichai and Hosaka 2006). Thus, it is highly probable that methylation-sensitive bands, or methylated DNA were also fixed to homozygotes in the advanced selfed progeny, following a Mendelian inheritance except for those which participated epigenetically as described above.

DNA methylation is generally recognized to function to suppress gene expression as regulatory factors (Jacobsen and Meyerowitz 1997; Jones and Takai 2001). If so, homozygosity of methylated DNA in such regulatory factors suppresses gene expression, while its heterozygosity regulates depending on the gene actions, dominant, partial dominant or additive. Therefore, it can be suggested that inbreeding depression partly or primarily results from lower levels or fewer genes expressed simply due to homozygosity of methylated DNA in regulating factors, while heterosis is from higher levels or larger number of genes expressed simply due to heterozygous conditions between methylated and non-methylated DNA in the $F_{1}$ hybrid. Consequently, changes of heterozygous methylated DNA to homozygosity through one selfing would lead to suppression of $25 \%$ of regulatory genes in the genome for additive or dominant genes and $50 \%$ of them for digenic epistatis (additive $\times$ additive), so that inbreeding depression results in hybrid maize because both additive effects and epistatis effects are important genetic bases of grain yield in maize (Ma et al. 2007). Heterozygous conditions caused by hybridization could occur randomly and genome-widely in any methylated DNA. This was demonstrated by a genome-wide transcript analysis by Guo et al. (2006) using a series of maize hybrids with varying degree of yield and heterosis. They found that, although the proportion of allelic additively expressed genes was positively associated with hybrid yield and heterosis, there was no correlation between the over- or under-expression of specific genes with either yield or heterosis.

Quantitative traits will be controlled in large part by multiple dosage-dependent regulatory loci (Birchler et al. 2001). Heterosis is a result of "different alleles" being present at loci that contribute to the regulatory hierarchies that control quantitative traits (Birchler et al. 2003). The "different alleles", however, can arise from differently methylated DNA. Overdominance in a specific gene can be explained by a heterozygous DNA methylation-controlling regulatory gene, which activates both parents-derived independent genes and gene networks. Therefore, the major genetic models such as dominance, overdominance, and/or epistasis could be explained by heterozygosity/ homozygosity of methylated DNA occurring in a Mendelian fashion. However, our observation relied upon a single technique to detect DNA methylation status. Further, this idea is proposed based on the assumption that DNA methylation suppresses gene expression as regulatory factors, and it was unable to distinguish whether homozygosity of methylation status (epigenetic homozygosity) or DNA sequence itself (genetic homozygosity) contributed to inbreeding depression in this study. Thus, further study is necessary to detect DNA methylation status using alternative techniques and to obtain direct evidence, for example by using highly homozygous inbreds with different degree of DNA methylation or by expression analysis of genetic loci associated with the methylation sensitive RAPD bands.

Acknowledgments We thank numerous reviewers and editors for improving the manuscript, and C. Phumichai, Faculty of Agriculture, Kasetsart University, Thailand, who extracted most of the DNA samples used in this study. This study was partly supported by Calbee Potato Inc. and Hokuren Federation of Agricultural Cooperatives.

Open Access This article is distributed under the terms of the Creative Commons Attribution Noncommercial License which permits any noncommercial use, distribution, and reproduction in any medium, provided the original author(s) and source are credited.

\section{References}

Birchler JA, Bhadra U, Pal Bhadra M, Auger DL (2001) Dosage dependent gene regulation in multicellular eukaryotes: Implications for dosage compensation, aneuploid syndromes and quantitative traits. Dev Biol 234:275-288 
Birchler JA, Auger DL, Riddle NC (2003) In search of the molecular basis of heterosis. The Plant Cell 15:2236-2239

Bird AP (1992) The essentials of DNA methylation. Cell 70:5-8

Birhman RK, Hosaka K (2000) Production of inbred progenies of diploid potatoes using an $\mathrm{S}$ locus inhibitor $(\mathrm{Sli})$ gene and their characterization. Genome 43:495-502

Chan SW, Henderson IR, Jacobsen SE (2005) Gardening the genome: DNA methylation in Arabidopsis thaliana. Nat Rev Genet 6:351-360

Cipar MS, Peloquin SJ, Hougas RW (1964) Variability in the expression of self-incompatibility in tuber-bearing diploid Solanum species. Am Potato J 41:155-162

Clark SJ, Harrison J, Paul CL, Frommer M (1994) High sensitivity mapping of methylated cytosines. Nucl Acids Res 22:2990-2997

Comai L, Tyagi AP, Winter K, Holmes-Davis R, Reynolds SH, Stevens Y, Byers B (2000) Phenotypic instability and rapid gene silencing in newly formed Arabidopsis allotetraploids. Plant Cell 12:1551-1568

Coors JG, Pandey S (1999) The genetics and exploitation of heterosis in crops. American Society of Agronomy, Crop Science Society of America, and Soil Science Society of America, Madison

Crow JF (2000) The rise and fall of overdominance. Plant Breed Rev 17:225-257

Cubas P, Vincent C, Coen E (1999) An epigenetic mutation responsible for natural variation in floral symmetry. Nature 401:157-161

Doerfler W (1983) DNA methylation and gene activity. Annu Rev Biochem 52:93-124

Falconer DS, Mackay TFC (1996) Introduction to quantitative genetics, vol 4. Pearson Education Ltd, Harlow

Gibson G, Weir B (2005) The quantitative genetics of transcription. Trends Genet 21:616-623

Gonzalgo ML, Liang G, Spruck CharlesH, CH III, Zingg JM, Rideout WMIII, Jones PA (1997) Identification and characterization of differentially methylated regions of genomic DNA by methylation-sensitive arbitrarily primed PCR. Cancer Res 57:594-599

Grant-Downton RT, Dickinson HG (2005) Epigenetics and its implications for plant biology. 1. The epigenetic network in plants. Ann Bot 96:1143-1164

Grant-Downton RT, Dickinson HG (2006) Epigenetics and its implications for plant biology. 1. The 'epigenetic epiphany': epigenetics, evolution and beyond. Ann Bot 97:11-27

Gruenbaum Y, Naveh-Many T, Cedar H, Razin A (1981) Sequence specificity of methylation in higher plant DNA. Nature 292:860 862

Guo M, Rupe MA, Yang X, Crasta O, Zinselmeier C, Smith OS, Bowen B (2006) Genome-wide transcript analysis of maize hybrids: allelic additive gene expression and yield heterosis. Theor Appl Genet 113:831-845

Hatada I, Hayashizaki Y, Hirotsune S, Komatsubara H, Mukai T (1991) A genomic scanning method for higher organisms using restriction sites as landmarks. Proc Natl Acad Sci USA 88:95239527

Henikoff S, Comai L (1998) Trans-sensing effects: the ups and downs of being together. Cell 93:329-332

Henikoff S, Matzke MA (1997) Exploring and explaining epigenetic effects. Trends Genet 13:293-295

Heslop-Harrison JS (1990) Gene expression and rarental dominance in hybrid plants. Development Suppl: Genomic Imprinting, pp 21-28

Hosaka K, Hanneman RE Jr (1998a) Genetics of self-compatibility in a self-incompatible wild diploid potato species Solanum chacoense. 1. Detection of an $S$ locus inhibitor (Sli) gene. Euphytica 99:191-197

Hosaka K, Hanneman RE Jr (1998b) Genetics of self-compatibility in a self-incompatible wild diploid potato species Solanum chacoense. 2. Localization of an $S$ locus inhibitor (Sli) gene on the potato genome using DNA markers. Euphytica 103:265-271

Jacobsen SE, Meyerowitz EM (1997) Hypermethylated SUPERMAN epigenetic alleles in Arabidopsis. Science 277:1100-1103

Jones PA, Takai D (2001) The role of DNA methylation in mammalian epigenetics. Science 293:1068-1070

Kakutani T (2002) Epi-alleles in plants: inheritance of epigenetic information over generations. Plant Cell Physiol 43:1106-1111

Lamkey KR, Edwards JW (1999) The quantitative genetics of heterosis. In: Coors JG, Pandey S (eds) The genetics and exploitation of heterosis in crops. American Society of Agronomy Inc. Crop Science Society of America, Inc, Madison, pp 31-48

Leitch IJ, Bennett MD (1997) Polyploidy in angiosperms. Trends Plant Sci 2:470-476

Leonardi A, Damerval C, Herbert Y, Gallais A, de Vienne D (1991) Association of protein amount polymorphisms (PAP) among maize lines with performances of their hybrids. Theor Appl Genet 82:552-560

Levy AA, Feldman M (2004) Genetic and epigenetic reprogramming of the wheat genome upon allopolyploidization. Biol J Linn Soc 82:607-613

Li ZK, Luo LJ, Mei HW, Wang DL, Shu QY, Tabien R, Zhong DB, Ying CS, Stansel JW, Khush GS, Paterson AH (2001) Overdominant epistatic loci are the primary genetic basis of inbreeding depression and heterosis in rice. I. Biomass and grain yield. Genetics 158:1737-1753

Lippman ZB, Zamir D (2007) Heterosis: revisiting the magic. Trends Genet 23:60-66

Liu B, Wendel JF (2003) Epigenetic phenomena and the evolution of plant allopolyploids. Mol Phylogenet Evol 29:365-379

Lukens LN, Pires JC, Leon E, Vogelzang R, Oslach L, Osborn T (2006) Patterns of sequence loss and cytosine methylation within a population of newly resynthesized Brassica napus allopolyploids. Plant Physiol 140:336-348

Luo LJ, Li ZK, Mei HW, Shu QY, Tabien R, Zhong DB, Ying CS, Stansel JW, Khush GS, Paterson AH (2001) Overdominant epistatic loci are the primary genetic basis of inbreeding depression and heterosis in rice. II. Grain yield components. Genetics 158:1755-1771

Ma XQ, Tang JH, Teng WT, Yan JB, Meng XJ, Li JS (2007) Epistatic interaction is an important genetic basis of grain yield and its components in maize. Mol Breeding 20:41-51

Madlung A, Masuelli RW, Watson B, Reynolds SH, Davison J, Comai L (2002) Remodeling of DNA methylation and phenotypic and transcriptional changes in synthetic Arabidopsis allotetraploids. Plant Physiol 129:733-746

Marfil CF, Masuelli RW, Davison J, Comai L (2006) Genomic instability in Solanum tuberosum $\times$ Solanum kurtzianum interspecific hybrids. Genome 49:104-113

Matzke MA, Matzke AJ (1998) Epigenetic silencing of plant transgenes as a consequence of diverse cellular defence responses. Cell Mol Life Sci 54:94-103

McClelland M, Nelson M, Raschke E (1994) Effect of site-specific modification on restriction endonucleases and DNA modification methyltransferases. Nucl Acids Res 22:3640-3659

Meyer P, Saedler H (1996) Homology-dependent gene silencing in plants. Annu Rev Plant Physiol Plant Mol Biol 47:23-48

Pandey KK (1962) Interspecific incompatibility in Solanum species. Amer J Bot 49:874-882

Phumichai C, Hosaka K (2006) Cryptic improvement for fertility by continuous selfing of diploid potatoes using Sli gene. Euphytica 149:251-258

Phumichai C, Mori M, Kobayashi A, Kamijima O, Hosaka K (2005) Toward the development of highly homozygous diploid potato lines using the self-compatibility controlling Sli gene. Genome 48:977-984 
Powell W, Morgante M, Andre C, Hanafey M, Vogel J, Tingey S, Rafalski A (1996) The comparison of RFLP, RAPD, AFLP and SSR (microsatellite) markers for germplasm analysis. Mol Breed 2:225-238

Pushkarnath (1942) Studies on sterility in potatoes. 1. The genetics of self- and cross-incompatibilities. Indian J Genet Pl Breed 2:11-36

Rafalski JA, Tingey SV (1993) Genetic diagnostics in plant breeding: RAPDs, microsatellites and machines. Trends Genet 9:275-280

Reif J, Warburton ML, Xia XC, Hoisington DA, Crossa J, Taba S, Muminovíc J, Bohn M, Frisch M, Melchinger AE (2006) Grouping of accessions of Mexican races of maize revisited with SSR markers. Theor Appl Genet 113:177-185

Reyna-López GE, Simpson J, Ruiz-Herrera J (1997) Differences in DNA methylation patterns are detectable during the dimorphic transition of fungi by amplification of restriction polymorphisms. Mol Gen Genet 253:703-710

Riddle NC, Richards EJ (2002) The control of natural variation in cytosine methylation in Arabidopsis. Genetics 162:355-363

Riddle NC, Richards EJ (2005) Genetic variation in epigenetic inheritance of ribosomal RNA gene methylation in Arabidopsis. Plant J 41:524-532

Rieseberg LH, Noyes RD (1998) Genetic map-based studies of reticulate evolution in plants. Trends Plant Sci 3:254-259

Romagnoli S, Maddaloni M, Livini C, Motto M (1990) Relationship between gene expression and hybrid vigor in primary root tips of young maize (Zea mays L.) plantlets. Theor Appl Genet 80:769-775

Salmon A, Ainouche ML, Wendel JF (2005) Genetic and epigenetic consequences of recent hybridization and polyploidy in Spartina (Poaceae). Mol Ecol 14:1163-1175

Shull GH (1908) The composition of a field of maize. Ann Breeders Assoc Rep 4:296-301
Tsaftaris AS (1995) Molecular aspects of heterosis in plants. Physiol Plant 94:362-370

Tsaftaris AS, Kafka M, Polidoros A, Tani E (1999) Epigenetic changes in Maize DNA and Heterosis. In: Coors JG, Pandey S (eds) The genetics and exploitation of heterosis in crops. American Society of Agronomy. Inc. Crop Science Society of America, Inc, Madison, pp 195-203

Ushijima T, Morimura K, Hosoya Y, Okonogi H, Tatematsu M, Sugimura T, Nagao M (1997) Establishment of methylationsensitive-representational difference analysis and isolation of hypo- and hypermethylated genomic fragments in mouse liver tumors. Proc Natl Acad Sci USA 94:2284-2289

Williams JGK, Kubelik AR, Livak KJ, Rafalski JA, Tingey SV (1990) DNA polymorphisms amplified by arbitrary primers are useful as genetic markers. Nucl Acids Res 18:6531-6535

Xiao J, Li J, Yuan L, Tanksley SD (1995) Dominance is the major genetic basis of heterosis in rice as revealed by QTL analysis using molecular markers. Genetics 140:745-754

Yu SB, Li JX, Xu CG, Tan YF, Gao YJ, Li XH, Zhang Q, Maroof MA (1997) Importance of epistasis as the genetic basis of heterosis in an elite rice hybrid. Proc Natl Acad Sci USA 94:9226-9231

Zhang MS, Yan HY, Zhao N, Lin XY, Pang JS, Xu KZ, Liu LX, Liu B (2007) Endosperm-specific hypomethylation, and meiotic inheritance and variation of DNA methylation level and pattern in sorghum (Sorghum bicolor L.) inter-strain hybrids. Theor Appl Genet 115:195-207

Zhao XX, Chai Y, Liu B (2007) Epigenetic inheritance and variation of DNA methylation level and pattern in maize intraspecific hybrids. Plant Sci 172:930-938 